\title{
A MOZAIKCSALÁDOK CSALÁDTIPOLÓGIAI MEGKÖZELÍTÉSE A VÁSÁRLÁSI KONFLIKTUSOK VIZSGÁLATÁN KERESZTÜL
}

A mozaikcsaládok vásárlási döntéseiket a hagyományostól eltéró módon hozzák meg, jellegzetességük, hogy a családtagok speciális rokoni kapcsolatai miatt sokkal több konfliktust kell megoldaniuk, mint a hagyományos családmodellben élóknek. A szerzố tanulmányában a vásárlási döntések vizsgálatán keresztül rávilágít arra, hogy a mozaikcsaládok korábbi pszichológiai és szociológiai megközelítése és tipizálása mellett újabb típusok is azonosíthatók. A kutatás eredményei rámutatnak arra, hogy - ellentétben a korábbi kutatások eredményeivel - a mozaikcsaládok mindennapi életében, konfliktusaiban és ezek megoldásában nem feltétlenül a családhoz csatlakozott felnốtt vagy gyerek neme, életkora, a családon kívül éló gyerekek száma - tehát a családszerkezet - a meghatározó, hanem az abban élók egymással kapcsolatos viszonyai, alkalmazkodási képessége, egymás elfogadása, az egymásért történố felelősségvállalás mértéke.

Kulcsszavak: mozaikcsaládok, vásárlási szokások, fogyasztói magatartás

Napjainkra a hagyományos családformák megváltozása a világ számos pontján elterjedt társadalmi jelenség lett. Magyarországon a KSH adatai szerint (KSH Demográfiai portré, 2009) a házasságok fele válással végződik, minden hatodik gyermek él patchwork családban (Spéder, 2003). A nemzetközi pszichológiaiszociológiai szakirodalomban patchwork családnak nevezik azt a családformát, amely nem egy szülő́párból és közös gyerekeiból, hanem különböző családrészek „összeolvadásából” jön létre (Ahuja et al., 1998). Az angol szakirodalomban gyakran a ,stepfamily" kifejezést is használják, illetve a „blended family” (kevert család) vagy „,reconstituted family” (újjáalakult család) említése is elófordul. A mozaikcsalád olyan család, ahol a pár egyik vagy mindkét tagjának már van gyermeke az előzô kapcsolatából (Kurdek, 1995). A pár azon tagját, aki nem biológiai szülóje a gyermeknek, mostohaszülónek nevezik (mostohaanya vagy mostohaapa) (Mintel, 2005).

Számos nemzetközi kutatás foglalkozik a mozaikcsaládokban zajló pszichés folyamatok vizsgálatával
(Fisher - Leve - O'Leary - Leve, 2003), szociológusok a jelenség társadalmi okait és kihatásait kutatják (Cheal, 2002). A marketing-szakemberek részéról is készültek már tanulmányok a mozaikcsaládokkal kapcsolatban, mivel a sajátos és bonyolult családi kapcsolatrendszer miatt az ilyen családok fogyasztói magatartása markánsan eltér a hagyományos családmodellben élókétól (Tinson, 2007).

A tanulmány a mozaikcsaládok családi kapcsolataival foglalkozó kutatások és publikációk mellett egy új jelenséggel, a vásárlási döntési szerepekkel, a szerepek azonosításán túl pedig a mozaikcsaládok eltéró szerkezetével is foglalkozik. A mozaikcsaládok léte Nyugat-Európában és Észak-Amerikában mára már elfogadott és mindennapos lett. Az ilyen típusú családok számának növekedése azonban új kutatási területeket hozott felszínre, továbbá gazdasági szinten is érezhetố a hatása. A szekunder kutatások alapján az 1. ábra mutatja be a mozaikcsaládok megjelenésének hatását a tudományos kutatásokra és a vállalati szférára vonatkozóan. 


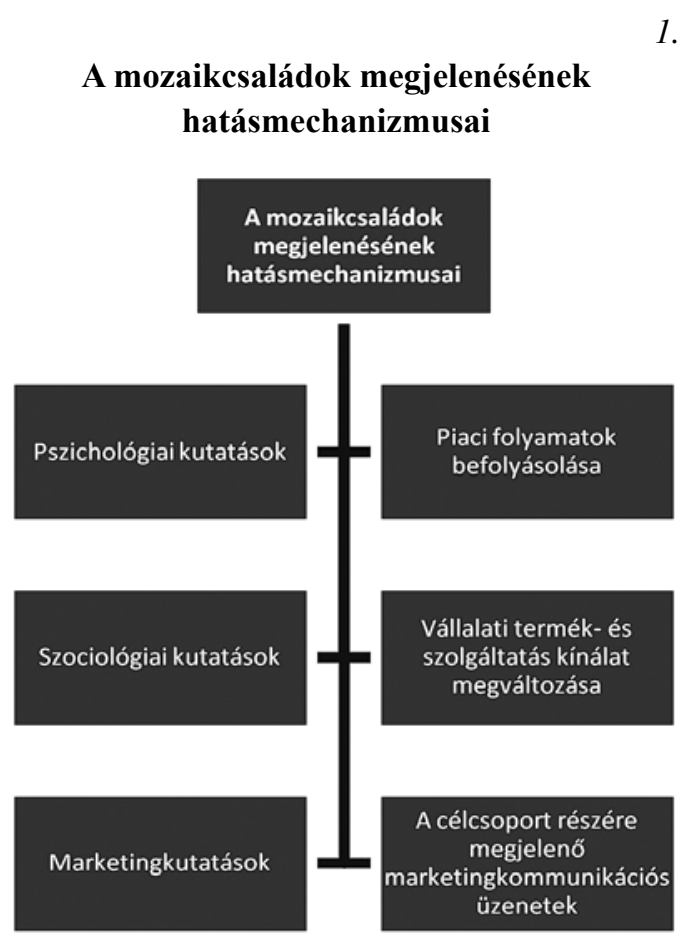

Forrás: szekunder kutatás alapján

A mozaikcsalád meghatározását többféle szemszögből közelítették már meg:

- a keverékcsalád (blended family) olyan család, amely különálló családokból házasság vagy más kapcsolat útján jött létre (Barker, 2003: p. 46.),

- újjáalakult család (reconstituted family): a szociológiai értelmezése két felnőtt házasság, együttélés vagy élettársi kapcsolat útján létrejött kapcsolatának, akiknek már vannak gyermekei elôzô kapcsolatukból,
- egy új család, ami egy széthullott család maradványaiból alakult (Biblarz - Gottainer, 2000).

A modern családi életciklus-modellek (2. ábra) tekinthetốk a mozaikcsalád-kutatások elôzményének, hiszen már az elváltakat, azok további kapcsolatait is megjelenítik (Murphy - Staples, 1979).

Az egyes lépcsőfokok különbséget tesznek a gyermekkel egy háztartásban élő szülő és a gyermeket csak bizonyos idônként látogató szülő között, így ezekből egy bonyolultabb családszerkezet is kialakítható.

\section{Szakirodalmi áttekintés}

A mozaikcsaládokról Németországban elsóként az 1980-as évek elején tettek említést (Sager - Brown et al., 1983). Korábban ilyen családok a gyermekes özvegyek újraházasodásaival jöttek létre, ám a válások számának nagyarányú emelkedésével kialakult a ma leginkább elterjedt mozaikcsalád (Clarke - Joshi, 2005). Sager (1983) szerint a mozaikcsalád két partner házassága (vagy együttélése) révén jön létre, és legalább egyikójük volt már házas. Visher és Visher (1995) olyan életközösségként definiálja a mozaikcsaládot, ahol legalább az egyik felnőtt pótszülő szerepben van. Minuchin (1990) rendszerszemléletú megközelítésben kezelte a mozaikcsaládokat, és egy családtérképet rajzolt fel, ahol a nukleáris családot egy pár, illetve szülői alrendszerból, vagy egy gyerek-testvér alrendszerból építette fel. Azok a szülók, akik a válás után már nem élnek együtt a családdal (Schumaker, 2005; Shoham et al., 2003), továbbra is fontos szerepet játszanak az új család életében is (Allan - Crow, 2001). McGoldrick és Gerson (1987) genogrammal egészítette ki a család-

A modern családi életciklus

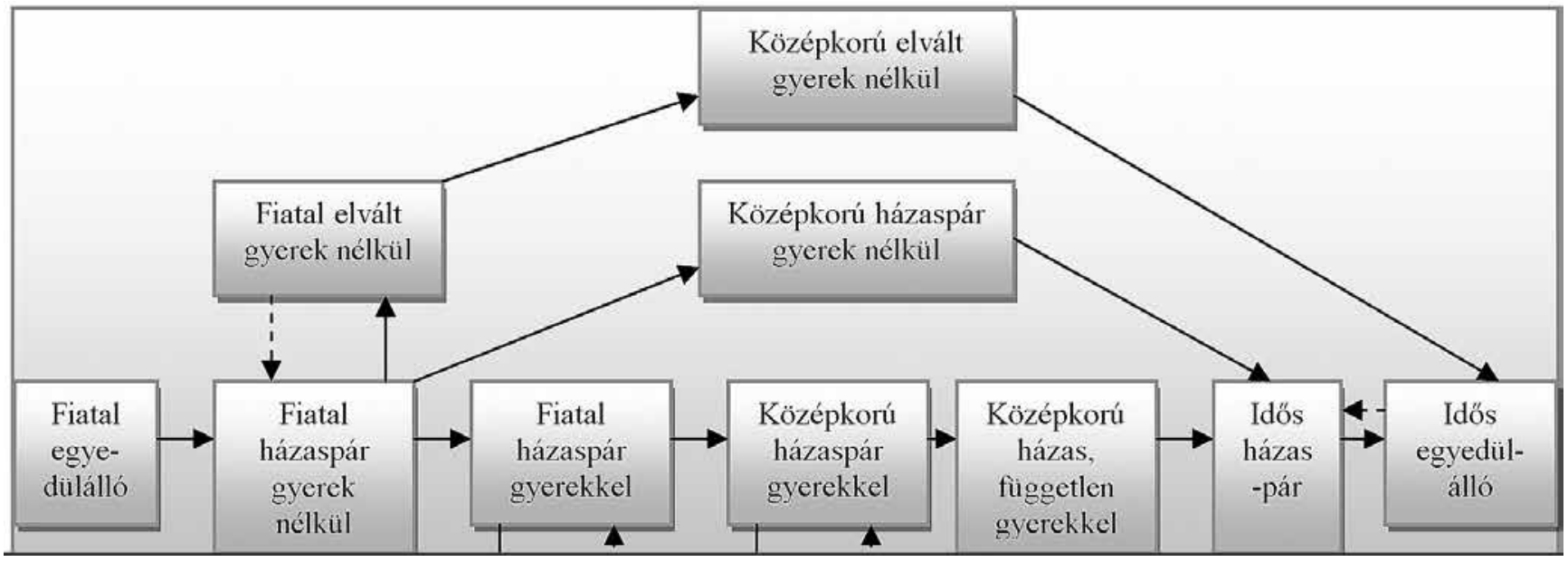

Forrás: Murphy - Staples (1979): A Modernized Family Life Cycle. in: Journal of Consumer Research, Vol. 6: p. 17. alapján 
térképet. A mozaikcsalád kívülról nézve nem sokban különbözik a nukleáris családtól, azonban közelebbrôl megvizsgálva jelentősen eltér attól (Hetherington, 1999). Visher és Visher strukturális összehasonlítása alapján megállapítható, hogy nagyon távol áll egymástól a két modell. Papernow (1980) két típust jegyzett fel (a) egyszerú mozaikcsalád-rendszer (egy szülő-gyerek rendszer és egy pótszülő), (b) összetett család (két szülő-gyerek alrendszer).

Krähenbühl (2001) és munkatársai kidolgoztak egy olyan tipológiát, mely azt is megkülönbözteti, hogy pótapa vagy pótanya csatlakozott a rendszerhez:

- pótanyás család: amikor egy nô csatlakozik egy férfihoz és annak vér szerinti gyermekéhez,

- pótpapás család: egy férfi csatlakozik a nôhöz és annak vér szerinti gyerekéhez,

- összetett mozaikcsalád: két részcsalád kapcsolódik össze, mindkét partner magával hozza a korábbi kapcsolatból származó gyerekeit,

- mozaikcsalád közös gyermekkel vagy gyermekekkel: a hozott gyerekek mellett egy vagy több közös gyermek is van a családban,

- részidôs mozaikcsalád: az elôzô kapcsolatból származó gyerekek a különélő szülővel és annak új partnerével bizonyos meghatározott időben együtt élnek.

A mozaikcsaládok kevésbé összetartóak (Corfman - Ehmann,1987), mint más családok, és az egyes családtagok közti különbségek miatt számos konfliktussal kell szembenézniük (Bien - Hartl - Teubner, 2002; Clingempeel - Brand - Clingempeel, 2004; Tinson Nancarraow, 2007). A gyerekeknek is kevesebb beleszólása van az egyes döntésekbe, mivel a családtagok nem szeretnék, hogy a helyzet bonyolultabb legyen (Tinson et al., 2008). A mozaikcsaládtagok számára a nehézségek egyik fő forrása, hogy tisztázatlanok a velük szembeni szerepelvárások (Fischer, 2005). Ezeknek a családoknak nincs közös történelmük (Fergusson et al., 1984), konfliktusok alakulhatnak ki a gyerekneveléssel kapcsolatosan (Felker et al., 2002) és a napi dolgokkal kapcsolatos döntéseknél is (Lawton - Sanders, 1994). Több kutatás is bizonyítja, hogy a gyerekeknél többször előfordulnak olyan problémák, mint szegénység, pszichés és viselkedési problémák, tanulási nehézségek, egészségügyi problémák (Cockett - Tripp 1994). Az egyik legnehezebben megoldható konfliktusokat az anyagi érdekellentétek okozzák (Bennett, 2008). A családforma azonban kihatással van a vásárlási döntéshozatalra (Foxman et al., 1989) és a folyamat jellegére is (Rogers - Rose, 2002; Brown, 2004). A fiatalok vásár- lási döntései és szokásai csak részben hasonlatosak a hagyományos családmodellben élő fiatal felnôttekéhez (Keller - Józsa, 2011).

\section{Kutatási kérdések}

A kutatás megkezdése előtt a következő kérdéseket fogalmaztam meg:

- Jellemzó-e a mozaikcsaládokra a hagyományos családmodellben élókétől eltérô vásárlási döntési mechanizmus?

- Lehetséges-e a mozaikcsaládok tipizálása a vásárlási döntési folyamatok alapján?

- Eltérően a korábbi szakirodalmi tipizálási módszerektől, felismerhetőek-e újabb mozaikcsaládtípusok a fenti tipizálás alapján?

\section{Primer kutatás}

A téma feldolgozását egy kvalitatív technikára alapuló mélyinterjús megkérdezéssel kezdtem. A kutatást 2011 őszén végeztem el, 62 mozaikcsaládban élő felnôttet kérdeztem meg, akik különbözô típusú mozaikcsaládokból kerültek ki (1. táblázat). Mintavételi módszerként a hólabdás mintavételt választottam, tekintettel a téma személyes jellegére.

1. táblázat

Az interjúalanyok mozaikcsalád-típusai

\begin{tabular}{|l|c|c|}
\hline \multicolumn{1}{|c|}{$\begin{array}{c}\text { A mozaikcsalád } \\
\text { típusa }\end{array}$} & \multicolumn{2}{c|}{ A mintában szereplók száma (fó) } \\
\hline Pótanyás & & 4 \\
\hline Pótapás & & 14 \\
\hline Összetett & & 18 \\
\hline Közös gyerekes & mostohaanyás & 4 \\
\hline & mostohaapás & 14 \\
\hline & összetett & 5 \\
\hline Részidős & & 3 \\
\hline
\end{tabular}

Forrás: saját szerkesztés

A mélyinterjú guide kifejlesztéséhez felhasználtam a nemzetközi és a hazai szakirodalomban található kutatások, szekunder adatforrások adatait, majd még a vezérfonal összeállítása előtt öt darab strukturálatlan mélyinterjút készítettem mozaikcsaládban élókkel. A kvalitatív kutatás elkészítésének két célja volt: (1) a kvantitatív kutatás elókészítése és (2) a kvantitatív kutatás során tesztelt hipotézisek felállítása.

A kvalitatív kutatás eredményeit felhasználva kérdőíves megkérdezést végeztem 2012 januárjától márciusig 142 mozaikcsalád és 184 hagyományos 
családmodellben élő körében, hólabdás mintavételi módszerrel. A mozaikcsaládban élők esetében a válaszadók nagy része nô volt (105 nô és 37 férfi töltötte ki a kérdőívet). A nók magas aránya azzal magyarázható, hogy a családdal kapcsolatos ügyeket is általában ôk intézik. A válaszadók átlagéletkora 39 év volt (2. táblázat).

A kvantitatív kutatásban szerepló mozaikcsaládban élő válaszadók mintájának bemutatása

\begin{tabular}{|l|l|}
\hline Nem & Nó: 105 \\
& Férfi: 37 \\
\hline Átlagéletkor & 39 év \\
\hline Iskolai végzettség & $35,2 \%$ diplomás \\
& $32,4 \%$ érettségizett \\
& $23,2 \%$ középfokú végzettségú \\
& $7,5 \%$ befejezett általános iskola \\
\hline Családi állapot & Elvált: $45,8 \%$ \\
& Házas: $51,4 \%$ \\
\hline A gyerekek száma a háztartásban & Egy gyerek: $19 \%$ \\
& Két gyerek: $39 \%$ \\
& Három gyerek: $28 \%$ \\
& Négy gyerek: $10 \%$ \\
\hline A nem vér szerinti gyerekek aránya a háztartásban & Öt gyerek: $6 \%$ \\
\hline A háztartáson kívül éló gyerekek aránya & Egy gyerek: $40 \%$ \\
& Két gyerek: $15 \%$ \\
& Három gyerek: $3 \%$ \\
\hline A háztartáson kívül éló gyerekek átlagéletkora & 20,14 év \\
\hline
\end{tabular}

Forrás: saját szerkesztés

\section{Családtipológiai megközelítések a kvalitatív kutatás alapján}

A mozaikcsaládok tipológiáját a pszichológiai szakirodalom aszerint állapította meg, hogy a családhoz ki csatlakozik, és az illetô hoz-e magával gyermeket az új családba (Mintel, 2005), továbbá, hogy az új kapcsolatból születik-e közös gyermek (Krähenbühl, 2001). Gyakorlatilag a mozaikcsaládon belüli vér szerinti kapcsolatokat vizsgálták, de az általam elvégzett kutatások alapján állítom, hogy a vizsgálatnak és a tipizálásnak más alapja is lehet. A mozaikcsaládok életében nagyon fontos tényezô, hogy a családban élő felnôttek hogyan képesek a mindennapokat, az ünnepeket, a konfliktusokat, a nevelési kérdéseket megoldani. Az ilyen jellegú problémák megoldását nem az határozza meg, hogy ki csatlakozott a családhoz, hanem inkább a családban élő szülók és a gyerekek értékrendje, hozzáállása, kommunikációja. Gondoljunk csak bele, hogy mindannyian ismerünk olyan mozaikcsaládokat, amelyek ,jól múködnek" és olyanokat is, amelyek nem. Miért is van ez? - tehetjük fel a kérdést. Ha megvizsgáljuk, hogy egy vásárlási döntés meghozatala során (kisebb értékú napi fogyasztási cikkek, nagyobb értékú beruházási javak, autó, nyaralás) kinek, milyen szerep jut, akkor a családban zajló mechanizmusok is felszínre kerülnek. Beleszólhat-e a feleség - anya - a hozzá

\section{2. táblázat}

vér szerint nem tartozó gyermekkel kapcsolatos döntésekbe, vagy a háztartáson kívül élő gyerek döntéseit figyelembe veszik-e például a családi program kialakításakor? A vásárlási döntési konfliktusok és azok megoldási módjainak vizsgálatán keresztül elkülöníthetjük a mozaikcsaládok különböző típusait, amely megközelítés a probléma lényegét más szemszögból világítja meg, mint a témával kapcsolatos korábbi kutatások.

A kvalitatív kutatásom során a mozaikcsaládok egy jellegzetes típusát azonosítottam. Ezekre a családokra jellemzô, hogy a férj akár egy generációval idősebb lehet a párjánál, jellemzôen élt már házasságban (esetleg élettársi kapcsolatban), amelyból született gyermeke (vagy gyermekei), akik már kirepültek, vagy éppen a családi fészek elhagyásának fázisában vannak. A család felnôtt nôtagja elsô házasságában vagy elsố hosszabb élettársi kapcsolatában él, jellemzően van közös gyermekük, ki jóval fiatalabb a férj első házasságából származó gyerekeinél. Az ilyen típusú mozaikcsaládokban gyakran elófordul, hogy a férjnek már unokája is van, aki gyakran hasonló korú, mint a második (harmadik) kapcsolatból származó gyermeke.

A patchwork családban élő szülók egyértelmú besorolása a családi életciklus-elméletek alapján lehetetlen. Az anya a családi életciklus alapján a házaspár hat év alatti gyermekkel vagy házaspár hat évnél idósebb gyermekkel kategóriába esik, igazából életkorának megfelelő családi életciklusszakaszban van. Az apa helyzete már bonyolultabb, hiszen a családi életcikluselméleteket alapul véve neki már az idôsebb házaspár független gyerekekkel szakaszban kellene lennie, ezzel szemben a feleség esetében a fentebb említett két szakasz valamelyikében van. Az életívmarketing (Törôcsik, 2011) elméletén keresztül azonban értelmez- 
hetôvé és besorolhatóvá válik az apa is: a családosok szakaszában van, felelősséget vállal másokért (lásd gyermek), de nem abban a korban teszi, melyben azt a családi életciklus-elméletek feltételezik (35 év alatti vagy 36-64 éves (Gilly - Enis, 1982).

Az ilyen jellegú családokban az általam feltárt fő konfliktusforrások:

- az apa éppen karrierje csúcsán van, míg az anya a karrierépítés fázisát éli, tehát más célok és preferenciák vezérlik a partnereket,

- az idôsebb szülố részérôl a segítő családtagok az életkorukból kifolyólag gyakran hiányoznak esetleg elhunytak -, és ez negatívan befolyásolja a gyermek szocializációs folyamatát is,

- a férj elózó házasságából származó gyermekekkel kapcsolatos kérdések, konfliktusok:

- öröklés,

- ajándékvásárlás,

- nagyobb értékú javak vásárlása (elektronikai eszközök, híradástechnikai eszközök),

- lakhatási kérdések megoldásában való szerepvállalás,

- tandíj, különórák, egyetemi tanulmányok finanszírozása, ennek mértéke,

- a gyerekek életében kiemelkedő fontossággal bíró eseményekben való részvétel: házasságkötés, karácsony, unokák születése számos konfliktushoz vezet a családon belül.

A kvalitatív kutatás során számos ilyen jellegú családban élővel készítettem interjút, és azt tapasztaltam, hogy bár sok esetben megpróbálják a felek a konfliktusaikat a családban élók számára megfelelôen kezelni, mégsem tudják. Ennek okait több oldalról is megközelíthetjük: egyrészt a kesze-kusza vérségi kapcsolatok, a mostohaszülő és mostohagyerek szerepek tisztázatlan volta is ide vezethet. Másrészt az anyagi kérdések, a mostohaszülő és a gyerekkel nem egy háztartásban éló szülő szerepe az anyagi kérdések megoldásában. Harmadrészt pedig a családban vagy családon kívül éló gyerekek és felnőttek közötti nagy korkülönbségból fakadó nehézségek is idetartoznak.

A mélyinterjúk során sokan nem vallották be, hogy az anyagi kérdések jelentik az egyik legfontosabb konfliktusforrást, de a mozaikcsaládosok szövetségének elnökével készített interjú során mégis az ellenkezője derült ki. A mozaikcsaládban élók alapvetôen a hagyományos családokhoz szeretnének hasonlítani, és nem szívesen beszélnek azokról a konfliktusokról, amelyek a család szerkezetének megváltozása miatt alakulnak ki.

\section{Családtipológiai megközelítések a kvantitatív kutatás alapján}

A kvantitatív kutatásom alapján azonban újabb tipizálási szempontok is felismerhetốk, különös tekintettel a mozaikcsaládok sajátságos vásárlási magatartására. Összesen négy klasztert sikerült azonosítani.

A fogyasztás fontos meghatározója továbbá az életstílus, amely szoros kapcsolatban áll a társadalmi státussal is. Hazánkban a középosztály viszonylag szúk réteg (a nyugat-európaihoz képest), ezért az életstílus-alapú szegmentáció korlátozottan alkalmazható. A szociodemográfiai ismérvek figyelembevétele pedig nélkülözhetetlen a pontos besoroláshoz. Az alacsony társadalmi státusúaknál a jövedelemkorlátok miatt a státus egyértelmúen meghatározza a fogyasztást (Veres et al., 2012).

A klaszterek azonosítására életstílussal kapcsolatos attitúdállításokat használtam (Veres szerk., 2010), összesen 34 darabot, melyeket a válaszadóknak 1-4es skálán kellett értékelniük. A klaszterek jellemzése során a 2,5-nél magasabb átlagos értéket kapott eredményeket vettem figyelembe. A kérdő́ivek kódolását követően SPSS adatelemzố program segítségével azonosítottam az egyes klasztereket, majd klasztercsoportonként kereszttáblás elemzéseket végezve össze tudtam hasonlítani a klaszterekbe tartozók vásárlási döntéseit és konfliktusait. Az egyes klaszterek vásárlási döntései és az ezekból származó ellentétek jellege, továbbá az anyagi terhek vállalásának kérdése az egyes klaszterekben eltérô. A tanulmány további részében a klasztercsoportok jellegzetességeit foglalom össze, kitérve a családtipológiai kérdésekre is.

\section{A klasztercsoportok, ezen keresztül további mozaikcsalád-típusok ismertetése}

\section{1. klaszter: Hagyományos családként múködö mozaikcsalád, amelyben a családon kívül élö gyermek szerepe elhanyagolható}

Családcentrikus, aktív, hagyománytisztelő. Ebbe a klaszterbe tartozó egyéneknek elsôsorban mások megbecsülése a fontos. Családcentrikusak, az élet feladataival igyekeznek megbirkózni, ha elbuknak, újrapróbálkoznak. Számukra fontos a hagyományok és a szokások tisztelete, de nyitottak az új dolgokra is. A csoportba tartozók a vásárlási döntéseiket előre átgondolják, nem jellemzố rájuk az impulzusvásárlás, inkább a racionális döntések. Gyakorlatias beállítottságúak (3. táblázat).

A csoportba nagyrészt felsőfokú végzettségú nôk tartoznak, 93\%-uknak van saját gyereke, $7 \%$-uk nevel 


\section{Az első klaszterbe tartozók attitűdállításainak átlaga csökkenő sorrendbe állítva}

\begin{tabular}{|c|c|}
\hline Ward Method & $\begin{array}{c}\text { Átlag } \\
\text { 1. klaszter }\end{array}$ \\
\hline Fontos, hogy érezzem, mások megbecsülnek & 3,7907 \\
\hline Ha elsőre nem sikerül, mindig meg kell próbálni még egyszer & 3,7442 \\
\hline Úgy gondolom, fontos, hogy a partnerünkkel tartós legyen a viszony & 3,7209 \\
\hline Fontos, hogy egész életünkben folyamatosan új dolgokat tanuljunk & 3,6977 \\
\hline Szabadidőmet elsősorban a családommal törekszem eltölteni & 3,6744 \\
\hline Fontos, hogy jól informáltak legyünk a világ dolgairól & 3,6744 \\
\hline Manapság fontos, hogy képesek legyünk egyszerre több dologgal is foglalkozni & 3,6512 \\
\hline Fontos a hagyományok és a szokások tisztelete & 3,6047 \\
\hline Szeretem a kihívásokat, az új dolgokat és a változatosságot az életben & 3,5814 \\
\hline A lehetőségeket akkor kell megragadni, amikor azok adódnak & 3,5116 \\
\hline Gyakorlatias szemléletmódom van & 3,4651 \\
\hline Szívesen feláldozom az időmet jó dolgokért & 3,3953 \\
\hline Szeretek kimozdulni otthonról & 3,3721 \\
\hline Szeretek új termékeket kipróbálni & 3,1163 \\
\hline Nem szeretem az embereket az életmódjuk alapján megítélni & 3,0465 \\
\hline Sok időt fordítok arra, hogy külsőm megfelelő legyen & 2,9535 \\
\hline Szeretek sokféle márkát, terméket kipróbálni & 2,9302 \\
\hline Szabadidőmet elsősorban a partneremmel igyekszem eltölteni & 2,9070 \\
\hline Az estéket általában csendesen, otthon töltöm & 2,8837 \\
\hline Jobban szeretek csapatban dolgozni & 2,8140 \\
\hline A szabadságom általában otthon töltöm el & 2,4884 \\
\hline Alapvetően szellemi beállítottságú vagyok & 2,4884 \\
\hline Csak a pénzért dolgozom & 2,4186 \\
\hline Az emberek tanácsot kérnek tőlem, mielőtt új dolgokat vásárolnak & 2,3488 \\
\hline Szabadidőmet elsősorban a barátaimmal törekszem eltölteni & 2,1163 \\
\hline Szeretek embereket ellenórizni & 2,0465 \\
\hline Sokkal fontosabb, hogy legyen elegendő szabadidőm, minthogy sokat keressek & 2,0465 \\
\hline Nem engedem a gyerekeket beleszólni, mit vásároljak & 1,7907 \\
\hline Sokat aggódom magamért & 1,7907 \\
\hline Néha olyasmit veszek magamnak, amire nincs szükségem & 1,6744 \\
\hline Ha valamit szeretnék, megveszem anélkül, hogy figyelembe venném az árát & 1,6279 \\
\hline Szabadidőmet egyedül szeretem eltölteni & 1,1860 \\
\hline
\end{tabular}

Forrás: saját kutatás

mostohagyereket a háztartásban. A klasztertagok 35\%a jelölte meg, hogy van a családon kívül élő gyerek. Havi nettó jövedelmüket tekintve átlagos jövedelemmel rendelkeznek (56\%-uk 70-130 ezer HUF/hó, 26\%-uk pedig 130-250 ezer HUF/hó összegból gazdálkodik). A napi cikkek - tehát a kisebb értékú bevásárlások esetében a nốk egyedül döntenek, míg a nagyobb értékú
3. táblázat bevásárlások esetében már közös döntésról van szó. Ha megfigyeljük a ruhavásárlási döntéseiket, akkor a nók saját maguk, míg a párjuk ruháinál közösen döntenek. A vásárlási döntések meghozatala, a vásárlási döntési szerepek meghatározzák egy családtag helyzetét a családon belül. A ruhavásárlás alapvetően nem számít túl nagy értékú terméknek, ezért esett erre a választás.

A családban éló gyerekek ruháinak vásárlásával kapcsolatban, függetlenül attól, hogy az a gyerek vér szerint kihez tartozik, vagy közösen döntenek a felnôttek, vagy pedig a nố dönt. Tehát nem tesznek a családon belül különbséget a ruhavásárlási döntésekben a szülók aszerint, hogy ki, kinek a vér szerinti szülője. A családon kívül élő gyerek szerepe ebben a klaszterben már más, mert a gyermeket neveló felnőtt döntése a ruhavásárlás, tehát a vér szerinti szülő́ nem veszi ki a szerepét ebben.

$\mathrm{Az}$ iskolaválasztás meghatározza egy gyermek mindennapjait és a jövơjét is, az ebben a döntésben vállalt szerep megvilágítja a szülő befolyását a gyermek életére, függetlenül attól, hogy egy háztartásban él vele vagy sem. Ebben a klaszterben ez is közös döntésnek számít - független attól, hogy a családon belül kinek a vér szerinti gyerekérôl van szó. A családon kívül élő gyerekkel kapcsolatban azonban az ôt nevelő szülő dönt. Ez azért is meglepó, mert mint említettem, az iskolaválasztás egy gyermek életében fajsúlyos kérdés. A mobilszámla kifizetése gyakran jelent konfliktusforrást, hogy ezt ki teszi egy mozaikcsaládon belül, megmutatja a családban élók szerepét. Hasonlóan az elóbb bemutatott területekhez, a közös döntések jellemzóek a családban élő gyerekeknél, de a családon kívüli gyerekkel kapcsolatban már csak az ôt nevelő szülő fizet. A nagyobb értékú (20 000 Ft feletti) vásárlásoknál azonban 
a szülók közösen döntenek, ha a családon kívül élố gyerekról van szó, tehát ebbe a folyamatba beleszól a mostohaszülő is. Nyilván a nagy értéke miatt. Összességében ez a klaszter a családban éló gyerekekkel próbál úgy viselkedni, mint a hagyományos családmodellben élố családok, fontos, hogy ezt a képet láttassák magukról a külvilág számára. A családon kívül élő gyerek szerepe azonban tényleges mostohagyerek-szerep, a vele kapcsolatos döntéseket az ôt neveló szülő hozza meg.

\section{2. klaszter:}

\section{Hagyományos családként múködố mozaikcsalád, amelyben a családon kívül élö gyermek szerepe részben meghatározó}

Tartós párkapcsolatra törekvő, családcentrikus, passzív, szellemi beállítottságú klasztercsoport. A szabadidejüket otthon szeretik eltölteni, nem mennek a dolgok elébe. Számukra a szabadidô a pénzkeresetnél is fontosabb, a munkában is inkább elvárják, hogy a dolgok megtörténjenek velük, mintsem elébük mennének. Szellemi beállítottságúak, szívesebben dolgoznak egy csapatban, mint vezetôként (4. táblázat).

Középfokú végzettséggel vagy szakképesítéssel rendelkező, többségében nói klaszter. 92\%-uknak van saját gyereke, $8 \%$-uk nevel mostohagyereket és 25\%-nak van családon kívül is gyereke.

Havi nettó jövedelmüket tekintve alacsony jövedelemkategóriába esnek (58\%-uk 70-130 ezer HUF/ hó közötti, 17\%-uk 70 ezer HUF/hó alatti keresettel rendelkezik). A napi cikkek esetében itt is alapvetóen nôi döntésról beszélhetünk, míg a nagybevásárlás inkább közös döntés. A ruhavásárlás - alacsonyabb árkategóriájú termék - esetén, ha a válaszadó párjának a ruháival kapcsolatos a döntés, akkor közös, de a családban élő gyerekek ruházatánál a nő dönt egyedül, függetlenül attól, hogy ki a vér szerinti szülője a gyermeknek. Ha azonban a családon kívül élő gye-
4. táblázat

A második klaszterbe tartozók attitúdállításainak átlaga csökkenố sorrendbe állítva

\begin{tabular}{|c|c|}
\hline Ward Method & $\begin{array}{c}\text { Átlag } \\
\text { 2. klaszter } \\
\end{array}$ \\
\hline Úgy gondolom, fontos, hogy a partnerünkkel tartós legyen a viszony & 3,7917 \\
\hline Szabadidőmet elsősorban a családommal törekszem eltölteni & 3,7500 \\
\hline Manapság fontos, hogy képesek legyünk egyszerre több dologgal is foglalkozni & 3,5417 \\
\hline Fontos, hogy jól informáltak legyünk a világ dolgairól & 3,5417 \\
\hline A szabadságom általában otthon töltöm el & 3,5000 \\
\hline Fontos, hogy egész életünkben folyamatosan új dolgokat tanuljunk & 3,5000 \\
\hline Az estéket általában csendesen, otthon töltöm & 3,3750 \\
\hline Ha elsőre nem sikerül, mindig meg kell próbálni még egyszer & 3,3750 \\
\hline Fontos, hogy érezzem, mások megbecsülnek & 3,2917 \\
\hline Alapvetően szellemi beállítottságú vagyok & 3,1667 \\
\hline Szívesen feláldozom az időmet jó dolgokért & 3,0417 \\
\hline Gyakorlatias szemléletmódom van & 3,0000 \\
\hline Fontos a hagyományok és a szokások tisztelete & 2,9583 \\
\hline Sokkal fontosabb, hogy legyen elegendő szabadidőm, minthogy sokat keressek & 2,7500 \\
\hline Szeretem a kihívásokat, az új dolgokat és a változatosságot az életben & 2,7500 \\
\hline Szeretek kimozdulni otthonról & 2,7083 \\
\hline Nem szeretem az embereket az életmódjuk alapján megítélni & 2,6250 \\
\hline Jobban szeretek csapatban dolgozni & 2,5833 \\
\hline Az emberek tanácsot kérnek tôlem, mielőtt új dolgokat vásárolnak & 2,1667 \\
\hline Szeretek embereket ellenőrizni & 2,0833 \\
\hline Csak a pénzért dolgozom & 2,0417 \\
\hline Szeretek új termékeket kipróbálni & 1,9583 \\
\hline Sokat aggódom magamért & 1,9583 \\
\hline Nem engedem a gyerekeket beleszólni, mit vásároljak & 1,6667 \\
\hline Szeretek sokféle márkát, terméket kipróbálni & 1,6250 \\
\hline Szabadidőmet egyedül szeretem eltölteni & 1,5833 \\
\hline Ha valamit szeretnék, megveszem anélkül, hogy figyelembe venném az árát & 1,5417 \\
\hline Szabadidőmet elsősorban a barátaimmal törekszem eltölteni & 1,5000 \\
\hline Néha olyasmit veszek magamnak, amire nincs szükségem & 1,4167 \\
\hline
\end{tabular}

rekról van szó, akkor közösen döntenek a vásárlásról, tehát valamennyire részt vesznek a családon kívüli gyermekkel kapcsolatos döntésekben is. Az iskoláztatási döntés alapvetôen közös, ám a családon kívül élő gyereknél az ôt nevelő szülő dönti el, milyen iskolába járjon a gyerek. Igaz ez a mobilszámla fizetésére is, valószínúleg ebben a típusú mozaikcsaládban a szülő́k a kisebb értékú termékek esetében részt vesznek a családon kívül élố gyerek életében, de a drágább termékek vagy az iskolaválasztásban már nem vesz részt az ôt nem nevelô szülő. 


\section{3. klaszter: Hagyományos családként múködó mozaikcsalád, amelyben a családon kivüil éló gyermek szerepe nagymértékben meghatározó}

Családcentrikus, aktív, gyakorlatias klasztercsoport. Az innováció iránt nyitottak, szívesen és gyakran próbálnak ki új termékeket és márkákat is, nem nevezhetôk márkahúnek. Szabadidejüket is szívesen töltik el az otthonukból kimozdulva, de a családjukkal. Számukra fontos a pénz, vásárlási döntéseikben impulzusvásárlók (5. táblázat).

Ez az egyetlen alapvetően férfi-klaszter. Tehát az attitúdállítások alapján történô klaszterbesorolásban a mozaikcsaládosoknál a férfiak egy csoportja markánsan elkülönül. Szakképesítéssel vagy középfokú végzettséggel rendelkeznek, 93\%-nak van saját gyereke, 7\%-uk rendelkezik mostohagyerekkel, 21\%-nak van a családon kívül élő gyereke. Havi nettó jövedelmüket tekintve $50 \%$ nak van 70-130 ezer HUF/ hó, 28\%-nak 131-250 ezer HUF/hó fizetése. A családon belüli vásárlási döntésekre jellemzô, hogy általában közösen hozzák meg döntéseiket, igaz ez a napi cikkekre vagy a nagybevásárlásokra is. A háztartásban élő saját, de nem közös gyerek ruháinak vásárlásakor már megoszlik a klasztertagok véleménye: egyedül dönt, a vér szerinti szülő dönt vagy pedig megbeszéli a párjával - mindhárom válasz hasonló arányban fordult elő a klasztertagok esetében.

Ebben a klaszterben fordult elő először, hogy a háztartáson kívül élő gyermekkel kapcsolatos vásárlási döntések, iskolaválasztási kérdések is közös döntésnek számítanak. Kivételt képez az a vér szerinti gyerek, aki az édesanyához tartozik, mert a mobilszámláját a vér szerinti anya fizeti.

\section{4. klaszter: Hagyományos családként múködö mozaikcsalád, amelyben a családon kívül élö gyermeknek nincs szerepe}

Partnerközpontú, passzív klasztercsoport, fontos számukra a külvilág véleménye.

A klasztertagok otthonülók, elsô sorban a párjuk a fontos számukra. Nem szeretik kipróbálni az újdonságokat. Vezetố típusok, nem csapatjátékosok, vásárlási döntéseiket is racionálisan hozzák meg, nem impulzusok alapján. Kitartóak, képesek a nehézségekkel szembenézni (6. táblázat).

5. táblázat

A harmadik klaszterbe tartozók attitüdállításainak átlaga csökkenő sorrendbe állítva

\begin{tabular}{|c|c|}
\hline Ward Method & $\begin{array}{c}\text { Átlag } \\
\text { 3. klaszter }\end{array}$ \\
\hline Szabadidómet elsősorban a családommal törekszem eltölteni & 3,3571 \\
\hline Fontos, hogy érezzem, mások megbecsülnek & 3,2857 \\
\hline Szeretek kimozdulni otthonról & 3,0714 \\
\hline Szeretek sokféle márkát, terméket kipróbálni & 3,0714 \\
\hline Szeretem a kihívásokat, az új dolgokat és a változatosságot az életben & 3,0714 \\
\hline Manapság fontos, hogy képesek legyünk egyszerre több dologgal is foglalkozni & 3,0000 \\
\hline Gyakorlatias szemléletmódom van & 3,0000 \\
\hline Fontos, hogy jól informáltak legyünk a világ dolgairól & 2,7857 \\
\hline Fontos, hogy egész életünkben folyamatosan új dolgokat tanuljunk & 2,7143 \\
\hline Néha olyasmit veszek magamnak, amire nincs szükségem & 2,6429 \\
\hline Szeretek új termékeket kipróbálni & 2,6429 \\
\hline Csak a pénzért dolgozom & 2,5714 \\
\hline Ha valamit szeretnék, megveszem anélkül, hogy figyelembe venném az árát & 2,5714 \\
\hline Úgy gondolom, fontos, hogy a partnerünkkel tartós legyen a viszony & 2,5000 \\
\hline Ha elsőre nem sikerül, mindig meg kell próbálni még egyszer & 2,4286 \\
\hline Szeretek embereket ellenórizni & 2,4286 \\
\hline Fontos a hagyományok és a szokások tisztelete & 2,4286 \\
\hline Sokat aggódom magamért & 2,4286 \\
\hline Szívesen feláldozom az időmet jó dolgokért & 2,2857 \\
\hline Az estéket általában csendesen, otthon töltöm & 2,2143 \\
\hline Szabadidőmet elsősorban a barátaimmal törekszem eltölteni & 2,2143 \\
\hline Az emberek tanácsot kérnek tőlem, mielőtt új dolgokat vásárolnak & 2,1429 \\
\hline Jobban szeretek csapatban dolgozni & 2,1429 \\
\hline Nem engedem a gyerekeket beleszólni, mit vásároljak & 2,0714 \\
\hline Nem szeretem az embereket az életmódjuk alapján megítélni & 2,0714 \\
\hline Sokkal fontosabb, hogy legyen elegendő szabad időm, minthogy sokat keressek & 2,0000 \\
\hline A szabadságom általában otthon töltöm el & 2,0000 \\
\hline Szabadidómet egyedül szeretem eltölteni & 1,7857 \\
\hline Alapvetően szellemi beállítottságú vagyok & 1,4286 \\
\hline
\end{tabular}

Forrás: saját kutatás 
6. táblázat tésére, a nagy értékú ajándékvá-

A negyedik klaszterbe tartozók attitüdállításainak átlaga csökkenő sorrendbe állítva

\begin{tabular}{|c|c|}
\hline Ward Method & $\begin{array}{l}\text { Átlag } \\
\text { 4. klaszter }\end{array}$ \\
\hline Úgy gondolom, fontos, hogy a partnerünkkel tartós legyen a viszony & 3,8571 \\
\hline Fontos, hogy érezzem, mások megbecsülnek & 3,7619 \\
\hline Ha elsőre nem sikerül, mindig meg kell próbálni még egyszer & 3,7619 \\
\hline Fontos, hogy egész életünkben folyamatosan új dolgokat tanuljunk & 3,7143 \\
\hline Fontos, hogy jól informáltak legyünk a világ dolgairól & 3,7143 \\
\hline Manapság fontos, hogy képesek legyünk egyszerre több dologgal is foglalkozni & 3,5714 \\
\hline Az estéket általában csendesen, otthon töltöm & 3,3810 \\
\hline A szabadságom általában otthon töltöm el & 3,3810 \\
\hline Szeretek kimozdulni otthonról & 3,2857 \\
\hline Szabadidőmet elsősorban a családommal törekszem eltölteni & 3,2381 \\
\hline Szeretek embereket ellenórizni & 3,2381 \\
\hline Szívesen feláldozom az időmet jó dolgokért & 3,1905 \\
\hline Jobban szeretek csapatban dolgozni & 3,1905 \\
\hline Gyakorlatias szemléletmódom van & 3,1905 \\
\hline Alapvetően szellemi beállítottságú vagyok & 3,1905 \\
\hline Szeretem a kihívásokat, az új dolgokat és a változatosságot az életben & 3,1429 \\
\hline Fontos a hagyományok és a szokások tisztelete & 3,0476 \\
\hline Csak a pénzért dolgozom & 3,0476 \\
\hline Az emberek tanácsot kérnek tőlem, mielőtt új dolgokat vásárolnak & 3,0000 \\
\hline Sokat aggódom magamért & 2,9524 \\
\hline Szeretek sokféle márkát, terméket kipróbálni & 2,9524 \\
\hline Szeretek új termékeket kipróbálni & 2,9524 \\
\hline Nem szeretem az embereket az életmódjuk alapján megítélni & 2,8095 \\
\hline Szabadidőmet elsősorban a barátaimmal törekszem eltölteni & 2,7143 \\
\hline Sokkal fontosabb, hogy legyen elegendő szabadidőm, minthogy sokat keressek & 2,6667 \\
\hline Nem engedem a gyerekeket beleszólni, mit vásároljak & 2,6190 \\
\hline Néha olyasmit veszek magamnak, amire nincs szükségem & 2,2381 \\
\hline Ha valamit szeretnék, megveszem anélkül, hogy figyelembe venném az árát & 2,1429 \\
\hline Szabadidőmet egyedül szeretem eltölteni & 2,0000 \\
\hline
\end{tabular}

Forrás: saját kutatás

Többségük középfokú végzettségú nô, akik átlagos jövedelemmel rendelkeznek. 95\%-nak van saját gyereke, 5\%-nak mostohagyereke, a családon kívül nevelódő gyerekek aránya viszonylag nagy: 38\%. A vásárlási döntések meghozatala a klaszteren belül eltér a korábbi csoportokétól.

Nemcsak a napi cikkeknél, hanem a nagybevásárlásoknál is a nô dönt. A családban élókkel kapcsolatos vásárlási döntéseket közösen hozzák meg, ám a családon kívül élő gyerekeknél az óket nevelő szülő dönt. Igaz ez a ruhavásárlásra, a mobiltelefon-számla fize- sárlásra, de még a nyaralásokra sem viszik el a családon kívül élő gyerekeket. Ez a klaszter elsôsorban nem családcentrikus, a párjuk a lényegesebb számukra. A vásárlási döntéseikből egyértelmúen kiderül, hogy a családon kívül élő gyereket nem veszik figyelembe, nem tekintik semmilyen mértékben sem a családhoz tartozónak. Meglepó módon ez nemcsak a családon kívül élő mostohagyerekekre, hanem a vér szerinti gyerekekre is igaz. A mélyinterjús kutatásomban is készítettem interjút olyan anyákkal, akik elmesélték, hogy a volt párjuk a közös gyerekekkel kapcsolatos anyagi terhek vállalásában csak a kötelezô mértéket veszi figyelembe, és nem többet.

\section{Összegzés}

A mozaikcsaládok vásárlási döntéseiket a hagyományostól eltéró módon hozzák meg, jellegzetességük, hogy a családtagok speciális rokoni kapcsolatai miatt sokkal több konfliktust kell megoldaniuk, mint a hagyományos családmodellben élóknek. Ugyanakkor a mozaikcsaládok sem tekinthetốk homogénnek. Tanulmányomban a vásárlási döntések vizsgálatán keresztül rávilágítottam arra, hogy a mozaikcsaládok korábbi pszichológiai és szociológiai megközelítése és tipizálása mellett újabb típusok is azonosíthatóak. A kutatás eredményeit összefoglalva elmondható, hogy - ellentétben a korábbi kutatások eredményeivel - a mozaikcsaládok mindennapi életében, konfliktusaiban és ezek megoldásában nem feltétlenül a családhoz csatlakozott felnốtt vagy gyerek neme, életkora, a családon kívül élő gyerekek száma - tehát a családszerkezet - a meghatározó, hanem az abban élók egymással kapcsolatos viszonyai, alkalmazkodási képessége, egymás elfogadásának, az egymásért történő felelősségvállalás mértéke. 
Bár a mozaikcsaládok megjelenése nem új keletú dolog, arányuk növekedésével potenciális célcsoportot jelentenek nemcsak a pszichológusok és szociológusok, hanem a jövô marketingszakemberei számára is. A világhálón barangolva vállalatok hirdetik termékeiket és szolgáltatásaikat a mozaikcsaládok részére. Amennyiben célcsoportként tekintjük a mozaikcsaládokat, a termékfejlesztés és -eladás területén elsôsorban a problémáik megoldására kell fókuszálni. A következő termékeket kifejezetten mozaikcsaládban élők számára készültek, pusztán csak fantázia kérdése a termékskála bóvítése:

- nászajándék mozaikcsaládok számára (a család sokszínúségét bemutató gyertya, kép, üdvözlőkártya, családfa),

- könyvek, szakmai kiadványok mozaikcsaládban élóknek (külön apáknak, anyáknak, gyerekeknek, testvéreknek),

- oktatóvideók és cd-kiadványok, számos jó tanáccsal és bemutatóval, a harmonikus családi élet kialakítása céljából,

- elôre elkészített levél a mostohaanyától a mostohagyerekek számára,

- különböző pólók, amelyek a mozaikcsalád elfogadását hirdetik,

- kalendárium a mozaikcsaládos anyukák számára,

- tanácsadó könyv anyáknak, hogyan menedzseljenek egy mozaikcsaládot.

Nemcsak a termékek, hanem a szolgáltatások területén is célcsoport ma már egy mozaikcsalád. Természetesen a vásárlási döntéseken túl problémát jelent a pénz kezelése, a biztosítások és az öröklés is. Az alábbi szolgáltatáslista kifejezetten mozaikcsaládok számára készült:

- bankszámla kezelése a mozaikcsaládon belül, tanácsadás, szoftvertámogatással,

- bankszámla -kezelési tanácsadás,

- tanácsadó blogok, oldalak, ahol pszichológusok, pedagógusok, mozaikcsaládokban élók ajánlják szolgáltatásaikat,

- moderátorok mozaikcsaládok konfliktusainak rendezésére.

A vállalati menedzsment és a humánerôforrás-kezelés gyakorlata szempontjából a mozaikcsaládosok számos kihívást is jelentenek. Esetükben több gyermek ellátásáról, bonyolultabb élethelyzetek megoldásáról beszélünk. A mozaikcsaládosokkal kapcsolatos vállalati gyakorlat napjainkban kezd kialakulni, egységes és jól bejáratott módszerekról még nem beszélhetünk.

A kutatás korlátait elsősorban a regionális jelleg (nagyrészt a nyugat-dunántúli régióból származó minta), másrészt a hólabdás mintavételből fakadó mintahomogenitás (nagyrészt hasonló társadalmi rétegból származó családok) jelentik. Nehéz volt felderíteni, kik tartoznak mozaikcsaládba, ezért volt szükség a megkérdezettek általi további potenciális válaszadók ajánlására. Ebből adódóan a mintába sok hasonló értékrendú, beállítottságú alany került. Az alacsonyabb társadalmi státusú, hátrányos helyzetú mozaikcsaládosok elérhetôségének nehézségét is meg kell említeni mint kutatási korlátot. Ốk még kevésbé szeretnek megnyílni egy idegen előtt és a problémáikról beszélni, pedig egy ilyen családban sokkal több konfliktus, családi probléma fordulhat elő.

Náluk a kérdések helyes értelmezésének problémája is felmerül, félreérthetik vagy rosszul értelmezhetik a bonyolultabb kérdéseket. Statisztikai adatokat nem tartanak nyilván a mozaikcsaládban élók számáról és települések közti megoszlásáról, ezért a célsokaság meghatározása sem volt egyértelmú. Így a minta reprezentativitására vonatkozóan sincsenek releváns információk. További kutatásokat indokolhatnak az előbbi tények, egy országos mintán lefolytatott vizsgálat is új eredményeket szülhet (például érdekes kutatási kérdés lenne, hogy a budapesti és a vidéki mozaikcsaládosok vásárlási szokásaiban fellelhetốk-e különbségek).

A kérdőíves megkérdezésben azokat a termékeket és szolgáltatásokat érintettem, melyek vásárlásával kapcsolatos konfliktusok a kvalitatív kutatásban is felszínre kerültek. Egy további vizsgálat a termékek szélesebb körére is rákérdezhet, előfordulhat újabb kérdéses terület, illetve konfliktusforrás feltárása is.

\section{Felhasznált irodalom}

Ahuja, R.D. - Capella, L.M. - Taylor, R.D. (1998): Child influences, attitudinal and behavioural comparisons between single parent and dual parent households in grocery shopping decisions, Journal of Marketing Theory and Practice, Winter: p. 48-62.

Allan, G. - Crow, G. (2001): Families, Households and Society. Basingstoke: Palgrave MacMillan

Barker, R.L. (2003): The social work dictionary (5th ed.). Washington, DC: NASW Press

Bennett, C. (2008): Blended Family Finances - When it comes to remarriage, money issues are tricky. Kiplinger's Personal Finance Magazine, August Vol. 62, No. 8: p. 82-84.

Biblarz, T.J. - Gottainer, G. (2000): Family structure and children's success: a comparison of widowed and divorced single-mother families. Journal of Marriage and Family, Vol. 62: p. 533-548.

Bien, W. - Hartl, A. - Teubner, M. (2002): Stieffamilien in Deutschland. Eltern und Kinder zwischen Normalität und Konflikt. Opladen: Leske und Budrich 
Brown, S. (2004): Family structure and child well-being: the significance of parental cohabitation. Journal of Marriage and Family, Vol. 66: p. 351-367.

Cheal, D. (2002): Sociology of Family Life. Basingstoke: Palgrave MacMillan

Clarke, L. - Joshi, H. (2005): Children's changing families and family resources. in: Jenson, A.M. - McKee, L. (eds): Children and the Changing Family: Between Transformation and Negotiation. Abingdon: Routledge Falmer: p. 15-26.

Clingempeel, W.G. - Brand-Clingempeel, E. (2004): Pathogenic conflict families and children: what we know, what we need to know. in: M. Coleman - L. Ganong (eds.): Contemporary families: considering the past, contemplating the future. Thousand Oaks, CA: Sage: p. 244-261.

Cockett, M. - Tripp, J. (1994): The Exeter Family Study. Exeter: University of Exeter

Corfman, K.P. - Ehmann, D.R. (1987): Models of cooperative decision making and relative influence: an experimental influence of family purchase decisions. Journal of Consumer Research, Vol. 14: p. 1-13.

Felker, J.A. - Fromme, D.K. - Arnaut, G.L. - Stoll, B.M. (2002): A qualitative analysis of stepfamilies: the stepparent. Journal of Divorce \& Remarriage, 38: p. 125-142.

Fergusson, D. - Horwood, J. et al. (1984): A proportional hazards model of family breakdown. Journal of Marriage and the Family, 46: p. 539-549.

Fischer, E. (2005): Modern mostohák. Budapest: Saxum: p. 13-14.

Fisher, P.A. - Leve, L.D. - O'Leary, C.C. - Leve, C. (2003): Parental monitoring of children's behavior: variation across stepmother, stepfather, and two-parent biological families. Family Relations, 52: p. 45-52.

Foxman, E.R. - Tansuhaj, P.S. - Ekstrom, K. (1989): Family members' perception of adolescents' influence in family decision making. Journal of Consumer Research, Vol. 15, No. 4: p. 482-492.

Gilly, M.C. - Enis, B.M. (1982): Recycling The Family Life Cycle: A Proposal For Redefinition. in: Advances in Consumer Research. Vol. 9: p. 271-276.

Hetherington, E.M. (1999): Family functioning and adjustment of adolescent siblings in diverse type of families. in: Hetherington, E.M. - Henderson, S.H. Reiss, D. (Eds): Adolescent Sibling in Stepfamilies: Family Functioning and Adolescent Adjustment, Monographs of the Society for Research is Child Development. Vol. 64: p. 1-25.

Keller, V. - Józsa, L. (2011): Consumer Shopping Styles of Young Hungarian: The Results of an exploratory study. in: EMAC 2011-11 ${ }^{\text {th }}$ European Meeting on Ancient Ceramics: Conferenced Program and Abstracts. Konferencia helye, ideje: Vienna, Ausztria, 2011. 09. 29. - 2011. 10. 01 .
Krahenbühl, V. - Jellouschek, H. - Kohaus-Jellouschek, M. - Kohaus-Jellouschek, M. - Weber, R. (2001): Stieffamilien. Struktur-Entwicklung-Therapie. Freiburg im Breisgau: Lambertus Verlag

Kurdek, L.A. - Fine, M.A. et al. (1995): School adjustment in sixth graders: parenting transitions, family climate, and peer norm effects. Child Development, 66: p. 430-445.

Lawton, J. - Sanders, M. (1994): Designing effective behavioral family interventions for stepfamilies. Clinical Psychology Review, 14 (5): p. 463-496.

McGoldrick, M. - Gerson, R. (1987): Genogramas en la evaluación familiar. Barcelona: Editorial Gedisa: p. 20-180.

Mintel (2005): Marketing to Families. London: Mintel International Group Ltd.

Minuchin, S. (1998): Where is the family in narrative family therapy? Journal of Marital and Family Therapy, 24: p. 397-403.

Papernow, P.L. (1993): Becoming a Step family. San Francisco: Jossey-Bass Publishers

Rogers, K.B. - Rose, H.A. (2002): Risk and resiliency factors among adolescents experience marital transitions. Journal of Marriage and Family, Vol. 20, No. 3: p. 238-251.

Sager, C.J. - Brown, H.S. et al. (1983): Treating the Remarried Family. New York

Scumaker, D.K. (2005): Successful stepfamilies: a family life education program to address unique needs. Oxford, Ohio: Miami University

Shoham, A. - Dalakas, V. (2003): Family consumer decision making in Israel: the role of teens and parents. Journal of Consumer Marketing, Vol. 20, No. 3: p. 238-251.

Spéder Zs. (2003): Az európai családformák változatossága Párkapcsolatok, szülói és gyermeki szerepek az európai országokban az ezredfordulón. Budapest: $\mathrm{KSH}$

Tinson, J. - Nancarrow, C. - Brace, I. (2008): Purchase decision making and the increasing significance of family types. Journal of Consumer Marketing, Vol. 25, No. 1: p. 45-56.

Tinson, J. - Nancarraow, C. (2007): Growing up: tweenagers involvment in family decision making. Journal of Consumer Marketing, Vol. 24, No. 3: p. 160-170.

Törócsik M. (2011): Fogyasztói magatartás, insight, trendek, vásárlók. Budapest: Akadémiai Kiadó

Veres Z. (szerk.) (2010): Életstílus alapú fogyasztói szegmensek Magyarországon, Szegedi Tudományegyetem Gazdaságtudományi Kar Üzleti Tudományok Intézete

Veres Z. - Andics J. - Hetesi E. - Prónay Sz. - Kovács P. - Hlédik E. - Vajda B. (2012): Regionális sajátosságok a fogyasztók szabadidős aktivitásában, vásárlási és márkapreferenciáiban. in: Bajmócy Z. - Lengyel I. Málovics Gy. (szerk.): Regionális innovációs képesség, versenyképesség és fenntarthatóság. Szeged: JATE Press: p. 354-377.

Visher, E.B. - Visher, J.S. (1995): Stiefeltern, Stiefkinder und ihre Familien, Probleme und Chancen. Weinheim und München 